\title{
Understanding Lies Based on Evolutionary Psychology: A Critical Review
}

\author{
Silvio José Lemos Vasconcellos*, 1 \\ Orcid.org/0000-0001-6415-7494 \\ Matheus Rizzatti ${ }^{1}$ \\ Orcid.org/0000-0001-9904-0405 \\ Thamires Pereira Barbosa ${ }^{1}$ \\ Orcid.org/0000-0002-7292-9148 \\ Bruna Sangoi Schmitz ${ }^{1}$ \\ Orcid.org/0000-0003-3255-5011 \\ Vanessa Cristina Nascimento Coelho ${ }^{2}$ \\ Orcid.org/0000-0001-8478-9587 \\ Andrea Machado ${ }^{1}$ \\ Orcid.org/0000-0002-9208-3776
}

\author{
${ }^{1}$ Universidade Federal de Santa Maria, Santa Maria, Rio Grande do Sul, Brasil \\ ${ }^{2}$ Universidade Luterana do Brasil, Santa Maria, Rio Grande do Sul, Brasil
}

\begin{abstract}
The present article aims to propose a theoretical discussion regarding the role of lying based upon the Evolutionary Psychology perspective by shedding a new light on the main studies conducted in this area. In order to do so, this article addresses the phylogenies and ontogenies of the capability to lie, both suggesting that the rise of lying as a pro-social deed is intimately related with Homo sapiens incredibly broad and complex communication skills. Like so, the paper continues on expatiating on the underlying cognitive and neuronal mechanisms of lying and lying recognition, as well as the differences amongst genders concerning the ability to recognize deceit. Broadly, the present theoretic study may elucidate the current state of knowledge regarding the topic, thus signaling necessary and more promising paths for future studies to follow with the purpose of contributing to fields where the act of uttering lies is highly present, such as the judicial context.
\end{abstract}

Keywords: Evolutionary psychology, lying, deceit, evolution.

* Mailing address: Av. Roraima, 100, Camobi, Santa Maria - RS, Brazil. E-mail: silviojlvasco@hotmail.com, m4theus.rizzatti@gmail.com, thami.pereira@gmail.com, brunasangoischmitz@gmail.com, nessa.coelho@ hotmail.com and deiapsi93@gmail.com. 


\title{
O Entendimento da Mentira com Base na Psicologia Evolucionista: Uma Revisão Crítica
}

\begin{abstract}
Resumo
O presente artigo tem por objetivo propor uma discussão teórica sobre o papel da mentira a partir da perspectiva da Psicologia Evolucionista, trazendo uma nova luz sobre os principais estudos realizados nessa área. Para tanto, este artigo aborda as filogenias e ontogenias da capacidade de mentir, ambas sugerindo que a ascensão da mentira como ação pró-social está intimamente relacionada às habilidades de comunicação incrivelmente amplas e complexas do Homo sapiens. Assim, o artigo discute os mecanismos cognitivos e neuronais subjacentes ao reconhecimento de mentiras, bem como as diferenças entre os gêneros em relação à capacidade de reconhecer o engano. Em linhas gerais, o presente estudo teórico pode elucidar o estado atual do conhecimento sobre o tema, sinalizando percursos necessários e mais promissores para futuros estudos, com o objetivo de contribuir para campos onde o ato de proferir mentiras está muito presente, como o contexto judiciário.
\end{abstract}

Palavras-chave: Psicologia evolucionista, mentira, enganação, evolução.

\section{La Comprensión de la Mentira Basada en la Psicología Evolucionista: Una Revisión Crítica}

\section{Resumen}

El presente artículo tiene como objetivo proponer una discusión teórica sobre el papel de la mentira a luz de la Psicología Evolucionista a partir de los principales estudios desarrollados en esta área. El artículo discurre sobre la filogénesis y la ontogénesis de la capacidad de mentir, discutiendo los mecanismos que viabilizan la ocurrencia de la mentira en la especie humana. El trabajo sugiere que el desarrollo de la mentira como práctica pro-social está íntimamente relacionado con la vasta capacidad de comunicación del Homo sapiens, discurriendo sobre los mecanismos cognitivos y neurales subyacentes, así como la diferencia entre géneros en lo que se refiere al reconocimiento del engaño. En general, el presente estudio teórico puede elucidar el estado actual de conocimiento sobre el asunto, indicando caminos necesarios y más prometedores para nuevos trabajos, a fin de colaborar para campos de actuación donde el acto de proferir mentiras se hace más presente, como, por ejemplo, el contexto judicial.

Palabras clave: Psicología evolucionista, mentira, engano, evolución.

In his celebrated work "Dom Casmurro", the writer Machado de Assis said that lying is often as involuntary as breathing (Assis, 1899/2004). The word lying is synonymous with a falsification of information passed on to another person or to a larger group of people. The deception that is made possible through the act of lying is related, according to Hippel and Trivers (2011), to the very possibility of avoiding the truth being explained, to the ways of making its expression more difficult, to exaggerating different facts or even to causing certain real events to become doubtful.
Different studies reveal distinct results related to the average number of lies that individuals in civilized societies utter daily. Figures can range from 0.59 to 1.56 for a mean number of daily lies (De Paulo, Kashy, Kirkendol, Wyer, \& Epstein, 1996; George \& Robb, 2008; Hancock, Thom-Santelli, \& Ritchie, 2004). The differences in these works can be mostly explained by the characterization of the sample, which can involve both university students and the population in general, as well as the criteria adopted, although in most cases so-called altruistic lies are counted (Serota, Levine, \& Boster, 2010). 
Not every lie can, however, be classified as an antisocial action. The concept of the prosocial or "white lie" has been referred to in recent works, indicating that untruthfulness may in some circumstances not be a strategy to hurt another individual (Levine \& Schweitzer, 2015; Talwar \& Crossman, 2011). The anthropologist Simpson-Herbert noted, for example, that in some parts of Iran people were able to make a false invitation to dinner, and that act was acceptably understood as false by those who were receiving such an invitation (Barnes, 1996). In Russia, telling a Vranyo means recounting a fantastic and false story to which some listeners pretend to believe (Barnes, 1996). Other types of lies, however, can generate social losses at different levels, with it not being possible to classify them into a single category regarding this same criterion (Vrij, 2008).

The present work proposes a theoretical discussion about the evolutionary comprehension of the lie, contemplating an ontogenetic and phylogenetic comprehension of this phenomenon. It is understood that deepening this subject could generate advances in the so-called Psychology of the Lie (Farisha \& Sakkeel, 2015), as well as the consolidation of new studies in this field in Brazil, considering that this is an area still incipient in the country (Matias, Leime, Bezerra, \& Torro-Alves, 2015).

\section{Very Misleading Species}

Although devoid of a linguistic capacity in syntactic and compositional terms as is verified in the human being, it is now known that other species belonging to different orders are capable of deceiving. This means that, although these organisms cannot verbalize lies as an effective strategy for deception, they may deceive other organisms as a defense strategy, to obtain resources for their own subsistence or, more directly, to propagate their genes.

The Barred-tailed Hawk (Buteo albonotatus) can fool its prey by flying with members of other species. When the hawk is together with vultures of the genus Cathartes it cannot be detected by the prey when flying over them, since the birds of the this genus do not present predatory behavior similar to that of the hawk (Sick, 1997). The strategy of deception consists, in this case, of flying over prey without being perceived due to the possibility of being confused with birds of another species.

The beetle Atemeles pubicollis reveals a strategy of myrmecophily that can be classified as social parasitism. The Atemeles is able to generate chemical substances that allow it access to the colony of ants, whose entrance is conditioned to the identification of compatible allomones. Once inside, it is fed by the ants of the colony and then begins feeding on the eggs and larvae that were being sheltered in this environment (Parker, 2016).

In an experiment conducted on the island of Caya Santiago in Puerto Rico, rhesus monkeys (Macaca mulatta) were observed hiding food from other individuals of the same species (Hauser, 1992). It was also observed that this trend was more pronounced when other individuals were not observed in the vicinity of the food source, since, when discovered, this deception strategy was severely punished within the group (Hauser, 1992). Food concealment strategies have also been observed in spider monkeys (Ateles geoffroyi), long-tailed monkeys (Macaca fascicularis), chimpanzees (Pan troglodytes), mangabey monkeys (Cercocebus torquatus torquatus) and Togian island monkeys (Macaca tonkeana; Hall \& Bronsnan, 2016). In addition to some primates, the male Topi (Damaliscus lunatus) has been observed to emit false alarm cries in order to keep females away from dominant male territory, increasing their chances of mating (Bro-Jorgensen \& Pangle, 2010).

Some species may also adhere to the hoax strategy when certain physical attributes favored by sexual selection are artificially introduced into a competition scenario by the females. Sexual selection is based on a process of choosing morphological and behavioral characteristics, confrontation between males or choosing by the female, in order to direct a successful cross, generating reproductive advantages that tend to 
be maintained within the species (Scott, 2009). The ornithologist Sievert Rohwer dyed some birds know as Haris's sparrows (Zonotrichia querula) on the upper part of the head, causing certain males of the species to have the characteristics of a dominant animal, which were therefore chosen by the females. These same animals then began to adopt dominant and more aggressive behavior in their flocks, acting in accordance with how they were perceived by others (Rowher, 1977).

Although deception strategies are recurrent for different species, more current studies based on Game Theory reveal that truthfulness of information transmitted in social species tends to be more stable (Számadó, 2011). This trend is largely explained by the need for collective preservation of the means of subsistence (Számadó, 2011). Regardless of these considerations, it is known that other species are capable of deceiving, although only the human species can use verbalization for this purpose. It is then necessary to understand the way in which the lie is recurrent in Homo sapiens, considering the costs and benefits in social and individual terms of its occurrence.

\section{Lies and Language in Homo sapiens}

Although other species are capable of some levels of communication, none of them come close to the significant ability of an adult human to organize phrases from a repertoire spanning an average of ten thousand words (Oesch, 2016). These words can be combined to exaggerate, omit, or invent facts. It is not possible to date, in phylogenetic terms, the advent of the ability to lie in Homo sapiens. It is plausible to think, however, that the emergence of language from its syntactic and compositional properties has enabled this capacity on a large scale. The possibility of thinking from a counterfactual logic may be at the basis of the very expansion of the lie in the human species. Counterfactual thinking is focused on facts that have not happened, but could have happened and, like lies, the areas of the brain responsible for inhibitory control and working memory tend to be allocated (Briazu, Walsh, Deeprose, \& Ganis, 2017). The mechanisms linked to lying and counterfactual thinking tend to be potentiated in a correlative way along with ontogenetic development (Debey, Schryver, Logan, Suchotzki, \& Verschuere, 2015). This same relationship has also been made explicit in patients with impairment in frontal functions, including some degenerative diseases (Abe, 2009).

The evolution of Homo sapiens, in comparison to the other hominids that preceded them, culminated in the formation of larger groups, allowing situations of social interaction to become more recurrent. It is estimated that these groups reached an average of one hundred and fifty individuals who cohabitated certain spaces, using specialization and the division of tasks (Iñiguez, Govezensky, Dunbar, Kaski, \& Barrio, 2014). Cooperation strategies may also have enabled and intensified these interactions (Tomasello, 2003). Thus, the antisocial character that lies can assume does not seem to be in line with the selection of pro-social mechanisms that may have characterized the evolution of our species. On the other hand, a more recent understanding of this supposed paradox reveals that the lie may have contributed to the very sophistication of language (Dor, 2017). Since co-operation could be expected, but never unambiguously, assessing the intentions of others and having more precise resources to infer and communicate them became adaptive in this context. Greater linguistic recursion became, as postulated by Dor (2017), a multipurpose tool for coordinating distinct perspectives, allowing such interlocutions to favor individuals who are better able to deceive, as well as individuals who are better able to detect deception.

This possibility is mainly related, according to Dor (2016), to the fact that language is capable of instructing and guiding the imaginative processes. Undoubtedly, lying may involve the representation of alternative scenarios and this function can be fostered by linguistic processing. From this same perspective, there are pro-social 
lies that can facilitate the maintenance of a collaborative network within the group itself (Levine \& Schweitzer, 2015).

For Dor (2017), these processes evolved together, so that one cannot think of lying as a practice that would necessarily counteract the pro-social tendencies observed in the evolution of hominids. According to this author, since the human brain developed the ability to think counterfactually, conjecturing about possible, albeit often unlikely, outcomes, it has built up a greater ability to deceive using increasing linguistic recursion (Dor, 2017).

\section{Lying in Childhood}

The study of lying in childhood can be characterized as a field of increasing productions. To a large extent, this interest is due to the fact that the act of lying involves different cognitive functions emerging throughout childhood development. The ability to theorize about other minds is, in this sense, one of the crucial aspects for a child to use linguistic recursion in an attempt to deceive another child or adult, even when such a strategy is not antisocial (Cheung, Siu \& Chen, 2015; Williams, Moore, Crossman, \& Talwar, 2016). Inferring the unrelated mental states generated from the acts themselves is an essential condition for the child to plan and execute a lie. The so-called executive functions that develop during this stage will also play a central role (Leduc, Williams, Garibello, \& Talwar, 2017).

Some controversies still exist about the possible emergence of the rudiments of this ability in three-year-old children. In a classic study conducted by Lewis, Stanger, and Sullivan (1989), 38\% of the children who took a toy without being allowed to do so denied that they had taken it. The replications of these methods, in investigations carried out in different cultures, have shown that one-third of children in similar situations tend to act in the same way in this same age group (Hayashi, 2017). In this context, findings indicate that, on average, a child is fully capable of lying at forty months of age (Evans \& Lee, 2013). However, lies that can be classified as antisocial have been observed in children aged two and a half years (Evans \& Lee, 2013). This is consistent with the observations made by the proponents of the theory of evolution more than a century ago regarding the precocity of lies in human development (Darwin, 1877). Zanette, Gao, Brunet, Bartlett, and Lee (2016), using the facial expressions coding system developed by Paul Ekman, also demonstrated a different facial expression in children from six to eleven years of age, in relation to uttering pro- and antisocial lies.

In general, however, researchers agree that the emergence and sophistication of this ability tends to occur in a period prior to the school phase (Lavoie, Leduc, Arrudaa, Crossman, \& Talwar, 2017). In an earlier period, children are able to lie as a way to conceal a transgression, however, they are still not able to simulate a series of behavioral signs that can make a lie more plausible (Lavoie, Yachison, \& Crossman, 2017). In the period between three and six years, the number of daily lies tends to increase (Wilson, Smith, \& Ross, 2003). When types of lies are considered, a more recent study of participants aged 3 to 14 observed that occasional lies are more frequent at 3 years compared in adolescents of 14 years of age and that the amount of daily lies tends to decrease with age, regardless of gender. The frequency of lies decreases as the skill of mind theory is developed, that is, to think about the perspective of the other (Hayashi, 2017). A greater possibility of making use of antisocial lies by children increases with age when related to a more deficient theory of mind (Lavoie et al., 2017). This data, in turn, is consistent with the improvement of cognitive functions that will enable a greater ability to theorize about other minds, to express empathy in circumstances experienced by the child and to control interpersonal behaviors (Leduc et al., 2017).

With regard to the joint action of different cognitive functions involved in the lie, the preponderant role of these lies is currently being discussed. The work of Evans and Lee (2013) suggests, for example, the importance of working memory in the planning and executing 
of the lie in children. The study by Williams et al. (2016) indicates that inhibitory control may itself play a decisive role in the emergence of the ability to lie. From this perspective, working memory tends to be allocated more directly to more complex lies and, therefore, consistent with later stages of child development (Alloway, McCallum, Alloway, \& Hoicka, 2015).

\section{A Species Not Very Capable of Detecting Lies}

Although a more current understanding of the subject considers that evolution favored lying, as well as the tendency to identify lies in the context of interpersonal relations, our species still cannot be considered effective in detecting lies. We are more likely to infer that the words of others are true than to regard them as false (Moi \& Shanks, 2015). In general, the correct response indices in detection situations slightly exceed the $50 \%$ level in the general population and may be slightly higher for trained professionals, which is possible to verify in studies with greater ecological validity (O'Sullivan \& Ekman, 2004).

A number of physiological reactions tend to occur when healthy people lie. Changes in electrodermal activity, blood pressure, heart rate, respiratory rate and encephalic electrical activity are commonly observed in situations of lying (Vrij, 2008). The attempt to deceive another individual by means of spoken words usually demands, in this sense, a greater cognitive burden associated with these alterations (Vrij, 2008; Walczyk, Igou, Dixon, \& Tcholakian, 2013). The execution of this act tends to more directly activate the dorsolateral prefrontal cortex as well as the lower frontal region, both directly involved in the planning and execution of more complex cognitive activities (Abe, 2009). Emotional leaks, as denominated by Ekman and Friesen (1969) may also occur as non-spontaneous acts capable of generating very subtle indications of lying. Among them, the occurrence of asymmetric facial expressions or facial microexpressions can be highlighted (Ekman, Hager, \& Friesen, 1981). Other bodily signs indicative of lying may also be included in this category, for example emblems, which are gestures with specific and involuntary meanings (Ekman, 1992/2009).

Despite the plurality of the verbal and nonverbal behaviors suggestive of lying, the human species is unlikely to detect them in different situations of social interaction (Elaad \& Reizer, 2015). A comparative study between groups of individuals with mean ages of 20.6 and 70.7 years indicated that this capacity may decrease with time (Stanley \& Blanchard-Field, 2008). In another way, adolescents tend to overestimate their own ability to detect lies (Elaad et al., 2012). A negative state of humor capable of fostering greater skepticism about the report the individual receives may be a facilitating condition for detection, as suggested by some research in this field (Reinhard \& Schwarz, 2012).

In spite of this low accuracy related to the possibility of deciding whether the individuals with whom we interact are lying or not, it can be speculated that there is an unconscious processing of information that is performed automatically and is not perceived by the subject that observes the body language of the other person. Therefore, this processing can be explained by memories (i.e., by past experiences of situations where the individual perceived how other people behaved), thus trying to equate situations without justifying why the person changed their behavior. From the precursor work of O'Sullivan and Ekman (2004), in which the authors reported having found 29 individuals considered lie detection "wizards" among 12,000 people analyzed, who could discriminate lies and truth with greater than $80 \%$ accuracy, it was sought to comprehend the role of nonconscious processing in the detection of lies. In this study, only a small number of participants were able to detect the lie without being able to subsequently clearly explain the evidence used for their correct responses.

In these terms, it cannot be concluded that the human being is inclined to process, on a recurring basis, suggestive information in relation to the lies of others. In general, a bias to infer the truth about the reports made by our 
interlocutors seems to be a ubiquitous feature in Homo sapiens.

\section{Differences between Men and Women}

Few studies indicate the main differences regarding the behavior of men and women in relation to lying. Some studies, however, indicate more specific differences in comparative terms. In general, both men and women tend to be concerned with their own appearance and the image conveyed to others in social interaction situations (Tyler \& Feldman, 2004). However, men are more likely to distort information about their abilities, other personal characteristics and their past accomplishments (De Paulo et al., 1996; Ross \& Holmberg, 1990). Women, on the other hand, tend to lie more about intimate issues, and are more likely to lie to try to comfort people with whom they establish a relationship (Tooke \& Camire, 1991).

Other differences have been indicated in the scientific literature regarding the frequency of lies. In general terms, women usually lie more often in situations in which they interact in a non-anonymous way (Tyler \& Feldman, 2004). Men, on the other hand, lie more often when certain situations involve the possibility of financial gain (Dreber \& Johanneson, 2008). With regard to lies directed toward close friends or strangers, women generally tend to present higher levels of anxiety associated with these behaviors (Vasconcellos et al., 2017).

In an experiment conducted by Bell and De Paulo (1996), 48 women were presented with art paintings. They had to choose two works that they liked and two that they did not (not knowing that the artists would be present later in the same environment). When the art student responsible for producing the painting was introduced to the participants, the artist was favored with kind lies and praise in relation to the painting, without explicitly saying that they did not appreciate the work. In general, it was observed that the women, by lying about their aesthetic preferences, exhibited more positive feelings in an attempt to convince the artist. They highlighted, in this sense, details referring to the way in which they evaluated the works and the emotions involved in these procedures (Vrij, 2008).

Despite these findings, the neural correlates related to the differences highlighted still require a more accurate comprehension. In part, this incipient character is due to the very fact that, only recently, neuroimaging studies have begun to investigate gender differences in more complex cognitive functions (Marchewka et al., 2012). In another way, suggestive findings can be highlighted related to the fact that in men, compared to women, lying about personal issues seems to involve a greater cognitive burden and, in this sense, some additional cerebral regions are allocated to these purposes. The left medial frontal gyrus has been shown to be one of these areas (Marchewka et al., 2012).

\section{Integrating Recent Findings Based on Evolutionary Psychology}

Evolutionary Psychology emerged from the articulation between recent findings of Cognitive Psychology and other areas of knowledge, such as Neo-Darwinism, encompassing, from this, findings of behavioral genetics and assumptions of natural selection. This approach is based on the comprehension of different levels of causation with respect to human behavior (Varella, Santos, Ferreira, \& Bussab, 2013). In these terms, the so-called proximal causal levels are highlighted, which can be related to the history of the organism, to more immediate events and to the final or distal levels that refer to the phylogenesis itself (Varella et al., 2013). In order to make it possible to comprehend the evolutionary assumptions related to the act of lying it is necessary to distinguish the type of causation highlighted (Varella, Santos, Ferreira, \& Bussab, 2017).

An individual can lie due to the circumstances, this being an incontestable fact. A person can, for example, lie with the intention of not betraying a friend or even harming a colleague faced with an inquiry situation. In addition, it can be understood that some individuals lie more than others for reasons that can only be compre- 
hended from a biopsychosocial perspective also related to the intrafamilial and extrafamilial environment in which the person developed. An example of this would be psychopaths, whose condition is broadly characterized by symptoms linked to the so-called pathological lie.

Another example would be factitious disorder, in which the production of the symptom related to the lie may occur on a conscious level, however, the demand for attention that lies behind this symptomatology stems from factors related to the life history of this individual. In such cases, the patient is acutely and dramatically ill, with the ability to mimic signs and symptoms which require prolonged hospitalization, invasive diagnostic procedures or a long period of therapy involving drugs and surgery (Vasconcellos, 2017). These are, therefore, examples that certain tendencies to lie can be explained at a proximal causal level. The analysis of the lie proposed in this paper is, however, about the comprehension of the lie on a distal causal level.

We belong to a species prone to cooperation based on mechanisms that tend to embrace both targeted reciprocity and indirect reciprocity (Yamamoto, Leitão, \& Eugenio, 2017). Therefore, the act of lying seems to counteract the aforementioned tendency. After all, lying does not directly contribute to cooperation, considering the very fact that the transmission of untruthful information about any scenario in which a group of organisms may be involved will undermine any coordinated actions that aim to provide benefits for the group. This assertion becomes more plausible when one considers, for example, group hunting as a modality that characterized the evolution of hominids. Cooperation strategies tend to be, from this perspective, more stable and therefore more recurrent (Számadó, 2011). However, as the authors sought to show in this work, the lie occurs in our lives with a significant daily frequency, it is not easily identified by our peers and the cognitive capacities that make it viable are developed early.

Thus, it is important to understand that human beings have evolved from their own capacity to insert themselves in different situations of social interaction. Rivalizing with antagonistic groups or pursuing prey were some of these innumerable modes of interaction. Competing for higher levels of social status within the group, establishing temporary alliances and trying to persuade their peers were certainly other distinct modes. Emerging cooperative strategies in the context of the group may have, to some extent, evolved along with many other strategies that have proved to be antagonistic (Puurtinen, Heap, \& Mappes, 2015). In other words, competition and cooperation have become recurrent and not mutually exclusive with respect to human behavioral tendencies. This idea seems to be duly summarized in Robert Wright's phrase when he stated that: "We are highly gregarious, highly cooperative and highly competitive" (2000, p. 38).

Our co-operative mechanisms make us more likely to trust than to distrust, and in this sense, more likely not to correctly identify the lies of others, even if certain proximal causal conditions may counterbalance this predisposition. In another way, lying may also prove to be a shorter way to obtain direct gains that are not in line with altruistic strategies. For these purposes, the ability to convince another person can be a tributary of the ability to convince oneself in relation to how to present oneself to other individuals (Hippel \& Trivers, 2011). Selfdeception favored, in these terms, part of these mechanisms and language may have optimized them (Dor, 2017; Oesch, 2016).

From an evolutionary perspective, in addition to an understanding of supposedly antagonistic mechanisms in the species, it is also necessary to understand the gender differences. In order to do this, misunderstandings about this subject that fall into naturalistic fallacies must be avoided. The naturalistic fallacy, as formulated by Hume (1738-40), presents the demonstration, by reducing to the absurd the possibility of concluding value judgments from factual judgments, therefore, concerned with nature as it presents itself, without an ethical consideration about these same judgments (Brito, 2010). In 
this particular case, an example of mistaken comprehension capable of declining into a naturalistic fallacy would be to say that lying by men ought to be more tolerated than lying by women, since evolution contributes to the occurrence of these differences. It is important to note that Evolutionary Psychology can explore the marks of a long past in our psyche, however, it is not part of its purpose to advocate values to be socially reinforced in the present. Investigating tendencies is not and should not be synonymous with justifying choices. Even less so, when such choices will not contribute to a more egalitarian society.

Once such elucidations are considered, it can then be highlighted that men and women present relatively distinct, though not opposing, tendencies toward lying. It may be further pointed out that such differences are due to dissimilar adaptations generated over a long period of our evolutionary history. Women tend to be, therefore, a little more empathic, even when it comes to the act of uttering lies (Vrij, 2008). It can be considered that the affiliative circuit, responsible for the bonding ability and able to make higher levels of oxytocin available in women, could explain some of these differences. In the breastfeeding phase, women have a higher level of oxytocin, which brings a greater level of relaxation, reducing stress, anxiety, addictions and problems in the birth. It can be seen as the opposite side of adrenaline, since it reduces the effects of fight and flight on the nervous system and promotes greater interpersonal interaction (Moberg, 2003). Empathy seems to have been more favored in women than in men, although this ability also depends, to a large extent, on environmental factors related to ontogenetic development.

As this study sought to make clear, we are not the only species capable of deceiving. Other organisms manage to deceive individuals belonging to the same species or even to other genera quite effectively and to adapt them to their own needs. The deception strategy employed for these purposes may be more or less sophisticated in each case.
This broad capacity cannot be attributed to chance and the data explained here suggest that it can be seen to be deeply rooted in our psyche to the extent that it cannot be considered a mere social construction. To understand it from an evolutionary perspective is therefore a necessary and revealing undertaking. This enterprise also demands considerations and constant updates regarding the possibility of discussing recent findings of the scientific literature in this field.

\section{Final Considerations}

The present article sought to review and discuss scientific findings with diverse themes referring to the Psychology of the lie from the understanding of Evolutionary Theory. Through the articles reviewed, it was verified that some distinct species use behavioral strategies to deceive in order to obtain resources for their own subsistence or to propagate their genes. However, there is a differentiation between Homo sapiens and other species, considering that humans use linguistic resources to cover up or perform some more specific forms of deception.

The comprehension of lying from the perspective of evolutionary theory assumes relevance in Psychology, since it provides an understanding of the lie relating to the practices and experiences of the contexts in which man is inserted. In general, the importance ofnew studies should be highlighted aiming to corroborate the understanding of the process of uttering lies, explaining its underlying mechanisms in order to improve practices in the contexts where it is most present. Although the study presented is focused on basic research in general, it can be understood that some outstanding findings already suggest some applicability for better comprehension of the testimony of children and adults in the forensic context, considering the type of lie uttered, the levels of anxiety involved and the corresponding chronological changes.

The present work also sought to elucidate the importance of a duly grounded understanding of these issues, without incurring fallacies related to the support of counterproductive social values. 
It aimed, therefore, to carry out a critical review on the subject, capable of promoting advances in an area that is still incipient in Brazil.

\section{Authors' Contributions}

Substantial contribution in the concept and design of the study: Sílvio José Lemos Vasconcellos, Vanessa Cristina Nascimento Coelho and Thamires Pereira Barbosa.

Contribution to data collection: Bruna Sangoi Schmitz, Matheus Rizzatti and Andrea Machado.

Contribution to data analysis and interpretation: Bruna Sangoi Schmitz, Matheus Rizzatti, Andrea Machado, Vanessa Cristina Nascimento Coelho and Thamires Pereira Barbosa.

Contribution to manuscript preparation: Sílvio José Lemos Vasconcellos, Vanessa Cristina Nascimento Coelho, Thamires Pereira Barbosa, Bruna Sangoi Schmitz, Matheus Rizzatti, Andrea Machado.

Contribution to critical revision, adding intelectual content: Sílvio José Lemos Vasconcellos, Vanessa Cristina Nascimento Coelho and Thamires Pereira Barbosa.

\section{Conflicts of interest}

The authors declare that they have no conflict of interest related to the publication of this manuscript.

\section{References}

Abe, N. (2009). The neurobiology of deception: Evidence from neuroimaging and loss-of-function studies. Current Opinion in Neurology, 22(6), 594-600. doi: 10.1097/WCO.0b013e328332c3cf

Alloway, T. P., McCallum, F., Alloway, R. G., \& Hoicka, E. (2015). Liar, liar, working memory in childhood verbal deception. Journal of Experimental Child Psychology, 137, 30-38. doi: 10.1016/j.jecp.2015.03.013

Assis, M. de. (2004). Dom Casmurro. In M. de Assis, Obra Completa: Vol. I. Rio de Janeiro, RJ: Nova Aguilar. (Original work published in 1899)

Barnes, J. A. (1996). Um Monte de Mentiras: Para uma sociologia da mentira. Campinas, SP: Papirus.
Bell, K. L., \& DePaulo, B. M. (1996). Liking and lying. Basic and Applied Social Psychology, 18(3), 243-266.

Briazu, R. A., Walsh, C. R., Deeprose, C., \& Ganis, G. (2017). Undoing the past in order to lie in the present: Counterfactual thinking and deceptive communication. Cognition, 161, 66-73. doi: 10.1016/j.cognition.2017.01.003

Brito, A. N. (2010). Falácia naturalista e naturalismo moral: Do é ao deve mediante o quero. Kriterion: Revista de Filosofia, 51(121), 215-226. doi: 10.1590/S0100-512X2010000100011

Bro-Jorgensen, J., \& Pangle, W. M. (2010). Male topi antelopes alarm snort deceptively to retain females for mating. The American Naturalist, 176(1), 33-39. doi: 10.1086/653078

Cheung, H., Siu, T. S. C., \& Chen, L. (2015). The roles of liar intention, lie content, and theory of mind in children's evaluation of lies. Journal of Experimental Child Psychology, 132, 1-13. doi: 10.1016/j.jecp.2014.12.002

Darwin, C. (1877). A biographical sketch of an infant. Annals of Neurosciences, 17(4), 187-190. doi: 10.5214/ans.0972.7531.1017409

Debey, E., Schryver, M., Logan, G. D., Suchotzki, K., $\&$ Verschuere, B. (2015). From junior to senior Pinocchio: A cross-sectional lifespan investigation of deception Evelyne. Acta Psychologica, 160, 58-68. doi: 10.1016/j.actpsy.2015.06.007

De Paulo, B. M., Kashy, D. A., Kirkendol, S. E., Wyer, M. M., \& Epstein, J. A. (1996). Lying in everyday life. Journal of Personality and Social Psychology, 70, 979-995.

Dor, D. (2016). From experience to imagination: Language and its evolution as a communication technology. Journal of Neurolinguistics, 43(B), 107-119. doi: 10.1016/j.jneuroling.2016.10.003

Dor, D. (2017). The role of the lie in the evolution of human language. Language Sciences, 1-16. doi: 10.1016/j.langsci.2017.01.001

Dreber, A., \& Johannesson, M. (2008). Gender diferences in deception. Economic Letters, 99(1), 197-199. doi: 10.1016/j.econlet.2007.06.027

Ekman, P. (2009). Telling lies: Clues to deceit in the marketplace, politics, and marriage (Rev. Ed.). New York: WW Norton \& Company. (Original work published in 1992)

Ekman, P., \& Friesen, W. V. (1969). Nonverbal leakage and clues to deception. Psychiatry, 32(1), 88-106. 
Ekman, P., Hager, J. C., \& Friesen, W. V. (1981). The symmetry of emotional and deliberate facial actions. Psychophysiology, 18(2), 101-106.

Elaad, E., Lavy, S., Cohenca, D., Berholz, E., Thee, P., \& Ben-Gigi, Y. (2012). Lies, truths, and attachment orientations in late adolescence. Personality and Individual Differences, 52(6), 670673. doi: 10.1016/j.paid.2011.12.018

Elaad, E., \& Reizer, A. (2015). Personality correlates of the self-assessed abilities to tell and detect lies, tell truths, and believe others. Journal of Individual Differences, 36(3), 163-169. doi: 10.1027/1614-0001/a000168

Evans, A. D., \& Lee, K. (2013). Emergence of lying in very young children. Developmental Psychology, 49(10), 1958-1963. doi: 10.1037/ a0031409

Farisha, A. T., \& Sakkeel, K. (2015). Psychology of lying. The International Journal of Indian Psychology, 2(2), 46-51. Retrieved from http:// oaji.net/articles/2015/1170-1427635231.pdf

George, J. F., \& Robb, A. (2008). Deception and computer-mediated communication in daily life. Communication Reports, 21, 92-103. doi: 10.1080/089342110802298108

Hall, K., \& Brosnana, S. F. (2016). Cooperation and deception in primates. Infant Behavior \& Development, 48(A), 38-44. doi: 10.1016/j.infbeh.2016.11.007

Hancock, J. T., Thom-Santelli, J., \& Ritchie, T. (2004). Deception and design: The impact of communication technology on lying behavior. CHI Letters, 6(1), 130-136. doi: $10.1145 / 985692.985709$

Hauser, M. D. (1992). Costs of deception: Cheaters are punished in rhesus monkeys (Macaca mulatta). Proceedings of the National Academy of Sciences, 89(24), 12137-12139. Retrieved from http:/www.life.umd.edu/faculty/ wilkinson/BIOL608W/Hauser1992PNAS.pdf

Hayashi, H. (2017). Young children's difficulty with deception in a conflict situation. International Journal of Behavioral Development, 41(2), 175184. doi: 10.1177/0165025415607087

Hippel, W. V., \& Trivers, R. (2011). The evolution and psychology of self-deception. Behavioral and Brain Sciences, 34(1), 1-16. doi: 10.1017/ S0140525X10001354

Iñiguez, G., Govezensky, T., Dunbar, R., Kaski, K., \& Barrio, R. A. (2014). Effects of deception in social networks. Proceedings of the Royal Society, 281(1790), 1-9. doi: 10.1098/ rspb.2014.1195

Lavoie, J., Leduc, K., Arrudaa, C., Crossman, A. M., \& Talwar, V. (2017). Development Developmental profiles of children's spontaneous lie-telling behavior. Cognitive Development, 41, 33-45. doi: 10.1016/j.cogdev.2016.12.002

Lavoie, J., Yachison, S., \& Crossman, A. (2017). Polite, instrumental, and dual liars: Relation to children's developing social skills and cognitive ability. International Journal of Behavioral Development, 41(2), 257-264. doi: $10.1177 / 0165025415626518$

Leduc, K., Williams, S., Garibello, C. G., \& Talwar, V. (2017). The contributions of mental state understanding and executive functioning to preschool-aged children's lie-telling. British Journal of Developmental Psychology, 35(2), 288-302. doi: 10.1111/bjdp.12163

Levine, E. E., \& Schweitzer, E. M. (2015). Prosocial lies: When deception breeds trust. Journal of Experimental Social Psychology, 126, 88-106. doi: 10.1016/j.obhdp.2014.10.007

Lewis, M., Stanger, C., \& Sullivan, M. W. (1989). Deception in 3-year-olds. Developmental Psychology, 25(3), 439-443. Retrieved from https:// www.ecu.edu/cs-cas/psyc/upload/Lewis-Stanger-Sullivan-1989.pdf

Marchewka, A., Jednorog, K., Felkiewicz, M., Szeszkowski, W., Grabowska, A., \& Szatkowska, I. (2012). Sex lies and fmri - Gender differences in neural basis of deception. Plos One, 7(8), e43076. doi: 10.1371/journal.pone.0043076

Matias, D. W. S., Leime, J. J., Bezerra, C. W. A. G., \& Torro-Alves, N. (2015). Mentira: Aspectos sociais e neurobiológicos. Psicologia: Teoria e Pesquisa, 31(3), 397-401. doi: 10.1590/010237722015032213397401

Moberg, K. U. (2003). The oxytocin factor: Tapping the hormone of calm, love, and healing. Cambridge, MA: Da Capo Press.

Moi, W. Y., \& Shanks, D. R. (2015). Can lies be detectedunconsciously? Frontiers in Psychology, 6, 1221. doi: 10.3389/fpsyg.2015.01221

Oesch, N. (2016). Deception as a derived function of language. Fronties in Psycholoy, 7, 1485. doi: 10.3389/fpsyg.2016.01485

O'Sullivan, M., \& Ekman, P. (2004). The wizards of deception detection. In P. A. Granhag \& L. 
Stromwall (Eds.), The detection of deception in forensic contexts. London: Cambridge University Press.

Parker, J. (2016). Myrmecophily in beetles (Coleoptera): Evolutionary patterns and biological mechanisms. Myrmecological News, 22, 65-108. Retrieved from http://www.antwiki. org/wiki/images/5/52/Parker_2016.pdf

Puurtinen, M., Heap, S., \& Mappes, T. (2015). The joint emergence of group competition and within-group cooperation. Evolution and Human Behavior, 36(3), 211 217. doi: 10.1016/j. evolhumbehav.2014.11.005

Reinhard, M. A., \& Schwarz, N. (2012). The influence of affective states on the process of lie detection. Journal of Experimental Psychology: Applied, 18(4), 377-389. doi: 10.1037/a0030466

Ross, M., \& Holmberg, D. (1990). Recounting the past: Gender differences in the recall of events in the history of a close relationship. In J. M. Olson \& M. P. Zanna (Eds.), Ontario Symposium on Personality and Social Psychology. Selfinference processes: The Ontario symposium (Vol. 6, pp. 135-152). Hillsdale, NJ: Lawrence Erlbaum.

Rowher, S. (1977). Status signaling in Harris sparrows: Some experiments in deception. Behaviour, 61(1), 107-129. Retrieved from http://www.jstor.org/stable/4533813

Serota, K. B., Levine, T. R., \& Boster, F. J. (2010). The prevalence of lying in America: Three studies of self-reported lies. Human Communication Research, 36(1) 2-25. doi: 10.1111/j.14682958.2009.01366.x

Sick, H. (1997). Ornitologia brasileira. Rio de Janeiro, RJ: Nova Fronteira.

Scott, G. (2009). Essential animal behavior. Malden, MA: John Wiley \& Sons.

Stanley, J. T., \& Blanchard-Field, F. (2008). Challenges older adults face in detecting deceit: The role of emotion recognition. Psychology and Aging, 23(1), 24-32. doi: 10.1037/08827974.23.1.24

Számadó, S. (2011). Long-term commitment promotes honest status signaling. Animal Behaviour, 82(2), 295-302. doi: 10.1016/j. anbehav.2011.04.024

Talwar, V., \& Crossman, A. M. (2011). Predictors of children's prosocial lie-telling: Motivation, so- cialization variables, and moral understanding. Journal of Experimental Child Psychology, 110, 373. doi: 10.1016/j.jecp.2011.05.003

Tomasello, M. (2003). Origens culturais da aquisição do conhecimento humano. São Paulo, SP: Martins.

Tooke, W., \& Camire, L. (1991). Patterns of deception in intersexual and intrasexual mating strategies. Ethology and Sociobiology, 12(5), 345-364. doi: 10.1016/0162-3095(91)90030-T

Tyler, J. M., \& Feldman, R. S. (2004). Truth, lies and self-presentation: How gender and anticipated future interaction relate to deceptive behavior. Journal of Applied Social Psychology, 34(12), 2602-2615. doi: 10.1111/j.1559-1816.2004. tb01994.x

Varella, M. A. C., Santos, I. B. C., Ferreira, J. H. B. P., \& Bussab, V. S. R. (2013). Misunderstandings in applying evolution to human mind and behavior and its causes: A systematic review. EvoS Journal: The Journal of the Evolutionary Studies Consortium, 5(1), 81-107. Retrieved from https://www.researchgate.net/publication $/ 258995813$

Varella, M. A. C., Santos, I. B. C., Ferreira, J. H. B. P., \& Bussab, V. S. R. (2017). Mal-entendidos sobre a psicologia evolucionista: Somos dominados por genes ou por outros equívocos? In M. L. Vieira \& A. D. Oliva (Eds.), Evolução, cultura e comportamento humano (pp. 17-104). Florianópolis, SC: Edições do Bosque.

Vasconcellos, S. J. L. (2017). Porque os psicopatas de colarinho branco mentem melhor? A ciência explicando a enganação. Paracatu, MG: Buriti.

Vasconcellos, S. J. L., Santos, B. S., Morais, L. Q., Ferraz, R., Freitas, P. O., \& Silveira, J. F. (2017). Evidências de validade de uma escala para ansiedade em situações de mentira. Avaliação Psicológica, 15(3), 383-390. doi: 10.15689/ ap.2016.1503.11

Vrij, A. (2008). Detecting lies and deceit: Pitfalls and opportunities (2nd ed.). New York: Wiley.

Walczyk, J. J., Igou, F. D., Dixon, L. P., \& Tcholakian, T. (2013). Advancing lie detection byinducing cognitive load on liars: A review of relevant theories and techniques guided by lessons from polygraph-based approaches. Frontiers in Psychology, 4, 14.

Williams, S., Moore, K., Crossman, A. M., \& Talwar, V. (2016). The role of executive functions and 
theory of mind in children's prosocial lie-telling. Journal of Experimental Child Psychology, 141, 256-266. doi: 10.1016/j.jecp.2015.08.001

Wilson, A. E., Smith, M. D., \& Ross, H. S. (2003). The nature and effects of young children's lies. Social Development, 12(1), 21-45. doi: $10.1111 / 1467-9507.00220$

Wright, R. (2000). Não zero - A lógica do destino humano. Rio de Janeiro, RJ: Campus.

Yamamoto, M., Leitão, M., \& Eugenio, T. (2017). A perspectiva evolucionista no estudo da cooperação. In M. L. Vieira \& A. D. Oliva (Eds.), Evolução, cultura e comportamento humano (pp. 105-162). Florianópolis, SC: Edições do Bosque.
Zanette, S., Gao, X., Brunet, M., Bartlett, M. S., \& Lee, K. (2016). Automated decoding of facial expressions reveals marked differences in children when telling antisocial versus prosocial lies. Journal of Experimental Child Psychology, 150, 165-179. doi: 10.1016/j.jecp.2016.05.007

Received: 26/07/2017

$1^{\text {st }}$ revision: $31 / 10 / 2017$ Accepted: 13/01/2018

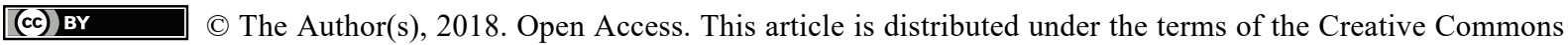
Attribution 4.0 International License (http://creativecommons.org/licenses/by/4.0/), which permits unrestricted use, distribution, and reproduction in any medium, provided you give appropriate credit to the original author(s) and the source, provide a link to the Creative Commons license, and indicate if changes were made. 